\section{Research Article}

(C) 2021 Temban et al.. This is an open access article licensed under the Creative Commons Attribution-NonCommercial 4.o International License (https://creativecommons.org/licenses/by-nc/4.o/)

\title{
Exploring Informal Learning Opportunities via YouTube Kids among Children During COVID-19
}

\author{
Magdeline M. Temban \\ Tan Kim Hua \\ Nur Ehsan Mohd Said \\ Faculty of Education, \\ Universiti Kebangsaan Malaysia, Malaysia
}

DOI: https://doi.org/10.36941/ajis-2021-0o83

\begin{abstract}
Education has been greatly affected by the COVID-19 pandemic. Children are becoming restless and stressed upon adjusting to emergent learning. An online platform that can regulate informal learning opportunities and entertainment for children during the worldwide crisis is needed. This need points towards the potential use of YouTube Kids (YTK); the app is age-appropriate and it offers popular videos with diverse contents. Studies have focused on the safety of YTK, but none has explored how young users could navigate their informal learning through the app. Fifty respondents aged 11 to 12 from a rural school in Sarawak, Malaysia participated in this study. Employing a mixed-methods research design, the study incorporated an online questionnaire and semi-structured group interviews as research instruments. Findings indicated distinctive features concerning the safety and multimodality of YTK. These features make YTK a great informal learning tool for children during present worldwide pandemic.
\end{abstract}

Keywords: Children, COVID-19, Informal Learning, technology, YouTube Kids

\section{Introduction}

Across the globe, education has been greatly affected by the COVID-19 pandemic. Approximately 1.6 billion children and teenagers are out of school because most countries have executed temporary closure of schools and other educational institutions. Although young learners have a lower mortality rate compared with adults (Abdulamir \& Hafidh, 2020), they can transmit or spread the virus, which is the main reason for school closures worldwide (K. H. Tan et al., 2020; Yew \& Tan, 2020). Adults, parents, and teachers are anxious about children's halted learning. Online learning has then become the frontier alternative for in-school education where parents take over teachers' role in guiding their children in the lesson and task completion. The emergent alternative has affected parents' productivity and responsibilities because they have to make learning devices, such as mobile phones or computers, and Internet access available for online learning.

Most primary and secondary school learners are accustomed to formal learning that allows faceto-face interaction with their teachers at schools. They have to abruptly cramp all physical aspects of 
learning into a digital lesson, where books are changed to a small non-textured screen. Hours are spent on phones, assessing assigned tasks and materials for different subjects. This new way of learning is laborious for many because young learners normally have a limited attention span. Besides, extended school closure and home confinement can have detrimental effects on the physical and mental health of children (Brazendale et al., 2017 and Brooks et al., 2020). Children are being restricted at home, and the state of physical and emotional restlessness is a natural result. Saxena and Saxena (2020) also argued the need to support children in maintaining their well-being and reducing anxiety during an emergency crisis such as this one. Overall, the pandemic affects an individual's physiological and psychological well-being, especially among children and young learners. If their overall well-being is not promptly addressed, they are likely to withdraw from online learning.

Malaysia studies that investigate digital learning are mostly concerned with a formal setting (e.g. Khairi-Fakhri \& Nur-Ehsan, 2020; Mohd-Iskandar et al., 2020; Muhammad-Asyraf \& Nur-Ehsan, 2020; Pavitthra \& Melor, 2020; Saiful-Islam et al., 2020). Fewer studies venture into the non-formal learning contexts which motivated the current study to explore informal learning opportunities for children using YouTube Kids (YTK). Studies on how YouTube is used as a resource for informal learning are limited despite the major proliferation of instructional and educational videos available via YouTube (the original app) and YTK (Burlington, 2016). Most scholars have recognized that children are often immersed in information and communications technology (ICT)-related activities in their homes and with their friends (Sefton-green, 2020). Scholars have usually focused on the effectiveness of using YouTube videos in formal classroom settings, but none has explored the possibilities of using YouTube or YTK as an educational tool beyond the classroom. Scholars should view YouTube from an educational perspective by paying attention to what and how children are learning (Lange, 2018). However, YouTube has been under-represented in literature as an informal learning tool for children.

The stressful online learning during the COVID-19 pandemic has inspired the researchers to investigate a medium that could provide young learners with the needed leisure and learning opportunities. Therefore, this study embodies the notable emergent educational context by investigating the benefits of the informal learning opportunities presented by YTK for children aged 11-12 years. The objectives of this study are to 1) understand what motivates children in using YTK app and 2) examine how children use YTK for informal learning. To achieve the specified objectives, this study seeks to answer the following research questions: 1) Why do children use YTK app? and 2) How does YTK benefit children's informal learning opportunities?

\section{Literature Review}

\subsection{Informal Learning}

Learning is an ongoing process that takes place every day at workplaces and schools when dealing with new adventures and challenges, or when looking at something in a new way (Livingstone, 2006). The famous urban quote 'Never Stop Learning' carries proper but bogus ideas. On the one hand, it encourages people to continue learning formally but on the other, the quote can be viewed as irrelevant because learning can never be stopped. Everyone learns all the time in various settings and contexts (Boileau, 2019). Learning is present even when an individual watches television for the whole day. People may learn about a new show and notice that slouching on the couch for a long time is bad for their health. Scholars have defined informal learning using various terms, but the concept remains similar.

In the 1970s, the term informal learning was introduced to contrast the term 'formal education', which was characterised as hierarchically organised learning provided by a school or related institution (Scribner \& Cole, 1973). Concerning children's learning, the term 'formal education' is used in this study to refer to traditional schooling. Formal learning is the word for learning performed in educational institutions, directed by teachers and executed according to a curriculum, following certain requirements set by the institution or some other mediums (Merriam et al., 2007). In formal learning, 
somebody else decides the learning objectives and curricula. Most westerners think about formal learning as education in schools and classrooms and with teachers who decide what, where, and how to learn.

According to Schugurensky (2000) and Rogers (2014), informal learning has three forms, namely self-directed learning, incidental learning, and unintentional learning (socialization). Self-directed learning occurs when the learner has the intention to learn and he is aware that learning is taking place. Schugurensky (2000) further highlights that self-directed learning happens without being assisted by other people such as teachers, parents, or peers. The second type of informal learning is incidental learning. In this type of learning, the learner has no intention to learn, although the learner only notices its occurrence after completing the task at hand successfully. The third form of informal learning is unintentional learning (socialization). This type of learning sees that learning still occurs although the learner has neither the intention nor the consciousness to learn. The knowledge that unintentional learning has taken place (through socialisation) could be evident immediately after or several years after the learning experience. Unintentional learning is often 'unanticipated or unorganized' and usually unacknowledged by the learner (Viberg et al., 2018).

\subsection{YouTube and YouTube Kids app}

YouTube and YTK have garnered worldwide popularity among children and their families in recent years. Children have been using the two platforms to watch videos online (Marsh et al., 2015). To know more about YTK, this study explored the YouTube literature. YouTube was created in 2015 as a videosharing platform where the users could upload and view videos while rating, sharing, reporting, commenting, and subscribing to other users' channels. It was founded by Chad Hurley, Steve Chen, and Jawed Karim in February 2015 (Gill et al., 2007). YouTube is considered an online video repository that offers family entertainment channels (Buzzi, 2014). Marketing research by Smarty Pants in 2017 describes YouTube as the 'King of Videos' where children watch a variety of content, which helps them with school and homework and gives them entertainment. The original YouTube is immensely popular among children (Eickhoff \& de Vries, 2010) that the developer created another app specifically for children, YTK.

YTK is designed and promoted as a world of learning and a fun app for kids. Office of Communications (2020) found that this new app is much preferred by young children and their families (Marsh et al. 2015). The app was created to make world exploration through online videos safer and simpler for children. The developers further signify that YTK includes a special feature of parental control such that parents can tailor experiences to their family needs. The app also incorporates search algorithms that filter videos according to the target audiences' age, search and viewing history, and other data (Lafrance, 2020).

In 2018, YouTube developers designed new filters to increase parental control (Izci et al., 2019) Parents can create individual profiles for each child under one account. They can also select the videos they want their children to watch or block any video that they find unsuitable for their children. Parents can turn off the search feature for young children or open and reset it to 'safer' algorithms. The safety features of the app also include a 'timer', which parents can use to set their children's screen time. The app will alert children when the session is over and will make parents worry less about their digital consumption.

\subsection{YouTube and Informal Learning}

YouTube was initially built to allow users to watch and share originally-created videos and comment on uploaded content. Academic scholars have begun seeing its social networking features (watch, share, and comment) as learning opportunities (Fleck et al., 2014). Numerous academic institutions are embracing YouTube by using it to create YouTube channels with educational content (Dyosi, 2018). YouTube is then further utilised to enhance formal and informal spaces or experiences (Yoo \& Kim, 
2013). Unintentional and self-directed learning is an important element of learning using social media because it supports informal learning at home and in the community (Dabbagh \& Kitsantas, 2012)

Informal learning is often related to ICT, Web 2.0, and social software that it becomes a byproduct of social activities. Technology-enhanced informal learning helps the users develop technical knowledge and skills that are constructivist, experiential, and situated (Latchem, 2014). The benefits of using YouTube as an informal tool is enjoyed by many because it continues to evolve into one of the biggest resources for educational content (Latchem, 2014). The attributes of informal learning environments can be highlighted as open-ended, non-threatening, and explorative while maintaining educational and enjoyable value (E. Tan, 2013). Therefore, YouTube fits the attributes of an informal learning environment (E. Tan, 2013). It provides the freedom to express oneself in an uncontrolled space with minimal barriers, thus making YouTube an appealing medium for informal learning (Burlington, 2016).

\section{Methods}

\subsection{Research Design}

This mixed-method study incorporated an online questionnaire (Appendix 1) and semi-structured interviews (Appendix 2). The questionnaire was generated in Google Forms and distributed to 50 respondents aged 11 to 12 years via WhatsApp. The questionnaire evaluated descriptive responses of the respondent on their perception of the use of YouTube and YTK as informal learning tools. A semistructured group interview was also used as a qualitative approach to examine YTK' potential in enhancing user experience and informal learning opportunities.

\subsection{Research Instrument}

The questionnaire was divided into two sections. The first section seeks to describe the respondents' demography and media accessibility. The second section aims to examine the respondents' perceptions of YouTube and YTK. The second section has a five-point Likert scale with 'Strongly Disagree', 'Agree', 'Neutral', 'Agree' and 'Strongly Agree'. Twelve items aim to investigate the perceptions of Year 5 and 6 pupils on the use of YouTube and YTK as informal learning tools. A Cronbach Alpha reliability test was conducted on the questionnaire. Table 1 shows the reliability test of the questionnaire with 0.79 which is deemed 'fairly high' by Taber (2018).

Table 1: Cronbach Alpha's reliability test

\begin{tabular}{|c|c|c|}
\hline \multicolumn{3}{|c|}{ Reliability statistics } \\
\hline Cronbach's Alpha & Cronbach's Alpha based on standardised items & N of items \\
\hline .790 & .791 & 12 \\
\hline
\end{tabular}

A semi-structured interview was used for this study because it allows the interviewer to be flexible for the discovery or elaboration of information given by the participants (Salmons, 2015). The interviewer used thematic questions to pursue related details for the study. Interviews were categorised into oneon-one interviews (either by phone or in-person) or group interviews (also known as a focus group) (Myers, 2008). The study employed a focus group as a data collection method after considering suitable factors especially participants' age and the type of data being aimed for the research. Given that the study deals with children aged 11-12 years, researchers must avoid uncomfortable situations where participants would only be telling what they believe the researcher wanted in a one-on-one interview. Thus, a focus group interview is used to facilitate conversation and participation among the participants.

A focus group is normally a group of six to eight participants who are purposely selected based 
on homogenous characteristics, such as age, gender and personalities (Nyumba et al., 2018). Thus, this study used a focus group with 10 children aged 11-12 years old. The researcher divided the participants into three groups of five. Rabiee (2004) states that a group size of six to eight participants is more manageable but a smaller group shows greater potential.

\subsection{Respondents}

The study involved English language learners $(\mathrm{n}=50)$ from a rural area - Long Lama, Baram in the state of Sarawak, Malaysia. It is a small town with a two-hour drive to the nearest city that is Miri, Sarawak. The town is situated along the Baram River and surrounded by forests, oil palms plantations, and quarries. The locals were mainly Chinese and Orang Ulu, and the others reside in the area for work.

The research sample comprised 22 girls and 28 boys aged $11-12$ years. Basic internet access was a privilege in the area and thus, the situation inspired the main researcher to make use of YTK as an informal learning tool in stimulating online learning. Some of the respondents had no smartphones, tablets or computers but shared a digital device with their parents or siblings.

Ten respondents were selected to participate in the semi-structured interviews using the purposive sampling method. The respondents were selected based on their age (11-12 years) and have accessibility to smartphones and the Internet. The respondents were of different ethnicity groups of Sarawak, such as Malays, Iban, and Orang Ulu who spoke their respective native language at home and English is a second language learnt at school.

\subsection{Data Collection and Analysis}

The researchers distributed the questionnaire in Year 5 and 6 WhatsApp groups. Instructions were given in the Malay Language to help students understand the requirements of the questionnaire. Parents were asked to assist if needed. Students were given two days to complete the survey. The data for the instrument were analysed and interpreted descriptively. The researchers identified the respondents who have used YTK. Ten students were selected as semi-structured interview participants. They were assigned into two focus groups. The interviews were conducted in two sections after school. The interview transcripts were analysed qualitatively.

\section{Results}

\subsection{Why do children use YTK?}

The first objective of this research is to understand what motivates children in using YTK App. To gain such input, an item on students' viewing preferences was included in the questionnaire.

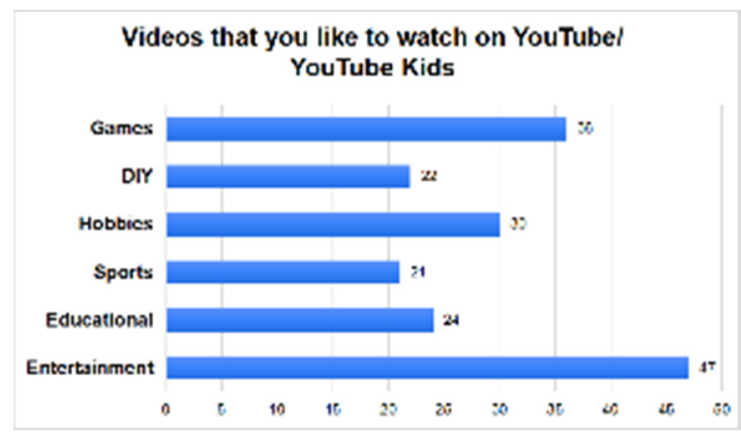

Figure 1. Survey on students' video preferences 
The findings reported that 'Entertainment-based' videos have the highest number of preferences. 47 out of 50 respondents agreed that they preferred to watch Entertainment-based videos on either YouTube or YTK. 'Games' came in second with 36 respondents, followed by 'Hobbies' with 30 respondents. Educational videos came in fourth with 24 respondents followed by DIY videos with 22 respondents. Sports videos have the lowest number of respondents. This finding thus helped the researchers to determine factors to be evaluated further to answer the first research question.

The researchers then used the factors based on video-preferences to weigh respondents' media use among the two apps as indicated in Table 2.

Table 2. Children's perceptions towards the use of YouTube and YTK

\begin{tabular}{|c|c|c|c|c|c|}
\hline Item & $\begin{array}{l}\text { Strongly } \\
\text { Disagree }\end{array}$ & Disagree & Neutral & Agree & $\begin{array}{l}\text { Strongly } \\
\text { Agree }\end{array}$ \\
\hline $\begin{array}{l}\text { A1. I have used YouTube } \\
\text { before. }\end{array}$ & $\begin{array}{l}0 \\
(0 \%)\end{array}$ & $\begin{array}{l}1 \\
(2 \%)\end{array}$ & $\begin{array}{l}5 \\
(10 \%) \\
\end{array}$ & $\begin{array}{l}14 \\
(28 \%) \\
\end{array}$ & $\begin{array}{l}30 \\
(60 \%) \\
\end{array}$ \\
\hline $\begin{array}{l}\text { A2. I use YouTube for } \\
\text { entertainment. }\end{array}$ & $\begin{array}{l}0 \\
(0 \%) \\
\end{array}$ & $\begin{array}{l}0 \\
(0 \%) \\
\end{array}$ & $\begin{array}{l}6 \\
(12 \%) \\
\end{array}$ & $\begin{array}{l}4 \\
(8 \%) \\
\end{array}$ & $\begin{array}{l}40 \\
(80 \%)\end{array}$ \\
\hline $\begin{array}{l}\text { A3. I use YouTube for } \\
\text { educational purposes. }\end{array}$ & $\begin{array}{l}3 \\
(6 \%) \\
\end{array}$ & $\begin{array}{l}8 \\
(16 \%) \\
\end{array}$ & $\begin{array}{l}14 \\
(28 \%) \\
\end{array}$ & $\begin{array}{l}11 \\
(22 \%) \\
\end{array}$ & $\begin{array}{l}14 \\
(28 \%) \\
\end{array}$ \\
\hline $\begin{array}{l}\text { A4. My parents are not worried } \\
\text { that I am using YouTube. }\end{array}$ & $\begin{array}{l}14 \\
(28 \%) \\
\end{array}$ & $\begin{array}{l}5 \\
(10 \%) \\
\end{array}$ & $\begin{array}{l}13 \\
(26 \%) \\
\end{array}$ & $\begin{array}{l}7 \\
(14 \%) \\
\end{array}$ & $\begin{array}{l}11 \\
(22 \%) \\
\end{array}$ \\
\hline $\begin{array}{l}\text { A5. I have learned a lot of new } \\
\text { things with YouTube. }\end{array}$ & $\begin{array}{l}1 \\
(2 \%) \\
\end{array}$ & $\begin{array}{l}3 \\
(6 \%) \\
\end{array}$ & $\begin{array}{l}7 \\
(14 \%) \\
\end{array}$ & $\begin{array}{l}10 \\
(20 \%) \\
\end{array}$ & $\begin{array}{l}29 \\
(58 \%)\end{array}$ \\
\hline $\begin{array}{l}\text { B1. I have used YouTube Kids } \\
\text { before. }\end{array}$ & $\begin{array}{l}22 \\
(44 \%)\end{array}$ & $\begin{array}{l}8 \\
(16 \%)\end{array}$ & $\begin{array}{l}7 \\
(14 \%)\end{array}$ & $\begin{array}{l}3 \\
(6 \%)\end{array}$ & $\begin{array}{l}10 \\
(20 \%)\end{array}$ \\
\hline $\begin{array}{l}\text { B2. I use You Tube Kids for } \\
\text { entertainment. }\end{array}$ & $\begin{array}{l}19 \\
(38 \%)\end{array}$ & $\begin{array}{l}5 \\
(10 \%)\end{array}$ & $\begin{array}{l}15 \\
(30 \%)\end{array}$ & $\begin{array}{l}4 \\
(8 \%)\end{array}$ & $\begin{array}{l}7 \\
(14 \%)\end{array}$ \\
\hline $\begin{array}{l}\text { B3. I use YouTube Kids for } \\
\text { educational purp oses. }\end{array}$ & $\begin{array}{l}20 \\
(40 \%)\end{array}$ & $\begin{array}{l}6 \\
(12 \%)\end{array}$ & $\begin{array}{l}12 \\
(24 \%)\end{array}$ & $\begin{array}{l}4 \\
(8 \%)\end{array}$ & $\begin{array}{l}8 \\
(16 \%)\end{array}$ \\
\hline $\begin{array}{l}\text { B4. My parents are not woried } \\
\text { that I am using YouTube Kids. }\end{array}$ & $\begin{array}{l}15 \\
(30 \%)\end{array}$ & $\begin{array}{l}4 \\
(8 \%)\end{array}$ & $\begin{array}{l}14 \\
(28 \%)\end{array}$ & $\begin{array}{l}3 \\
(6 \%)\end{array}$ & $\begin{array}{l}14 \\
(28 \%)\end{array}$ \\
\hline $\begin{array}{l}\text { B5. I have learned a lot of new } \\
\text { things with YouTube Kids. }\end{array}$ & $\begin{array}{l}19 \\
(38 \%)\end{array}$ & $\begin{array}{l}9 \\
(18 \%)\end{array}$ & $\begin{array}{l}11 \\
(22 \%)\end{array}$ & $\begin{array}{l}2 \\
(4 \%)\end{array}$ & $\begin{array}{l}9 \\
(18 \%)\end{array}$ \\
\hline
\end{tabular}

The result of the questionnaire is discussed in categories based on the mean differences between the use of YouTube and YTK. The questionnaire was not meant to use to compare YouTube and YTK' functionality but to help the researchers understand what makes YTK appeal to the children.

Table 3. Mean for children's perceptions towards the use of YouTube and YTK

\begin{tabular}{|l|c|c|}
\hline \multirow{2}{*}{ Categories } & \multicolumn{2}{|c|}{ Mean } \\
\cline { 2 - 3 } & YouTube & YTK App \\
\hline Entertainment viewing & 4.68 & 2.50 \\
\hline Educational viewing & 3.50 & 2.48 \\
\hline Daily usage & 3.20 & 1.64 \\
\hline Time spent & 4.08 & 1.92 \\
\hline Parents concerns & 2.92 & 2.94 \\
\hline Learning opportunities & 4.26 & 2.46 \\
\hline
\end{tabular}


In general, the questionnaire data reported higher means for all categories (Entertainment Viewing, Educational Viewing, Daily Usage Time Spent, and Learning Opportunities) for YouTube except for Parents' Concerns. This is mainly because only 20 out of 50 respondents (Figure 2) have used YTK before. Entertainment viewing shows the highest mean score as children generally watch online videos for entertainment purposes such as movies, shows, music videos, and more. The findings are coherent because most of the respondents were unfamiliar with the new app. Meanwhile, the highest mean score for YTK is on Parents' concerns. 'My parents are not worried that I use YTK' has a higher mean than 'My parents are not worried that I use YouTube'. Although most of the respondents were not familiar with YTK, they were aware of safety problems concerning original YouTube. This difference needs to be further clarified through semi-structured interviews because YTK has safety features that make it a supposedly better option than the original YouTube.

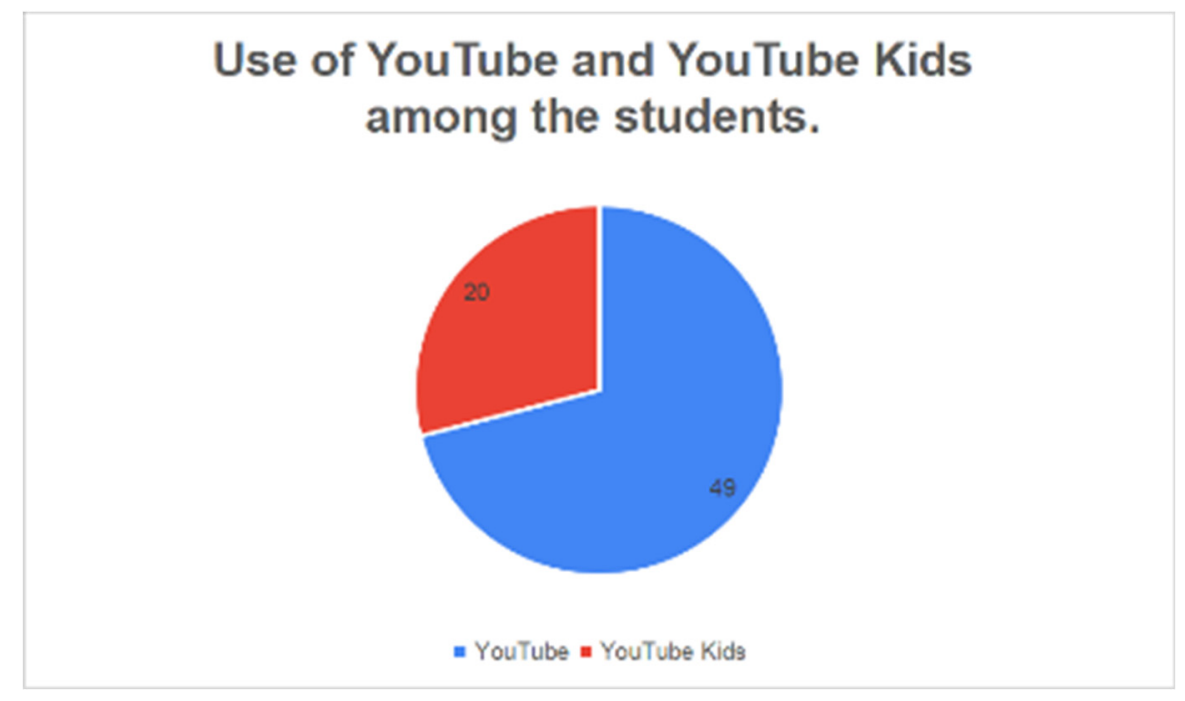

Figure 2. Use of YouTube and YTK among the students

As reported in Figure 2, only 20 out 50 respondents ever used YouTube Kids App, while a large majority of 49 respondents have used the original YouTube. This major distinction between the apps usage suggest that the overall respondents were more familiar with YouTube as they have used it before. They usually use it more for entertainment purposes than educational viewing. Students have spent more time on YouTube than YTK, which indicates that most of them do not have YTK on their mobile phones. Media availability thus affects children's digital exposure and awareness. Respondents agreed that YouTube offers learning opportunities for them. However, a survey on parents' concerns reflects unanimous responses, which allow for more discussion. The sole difference in the mean score on parental concerns reveals this factor as the main reason that motivates children in using YTK App. Parental concerns play a significant role in determining the reason for children's YTK usage.

\subsection{How do children benefit from YTK App as an informal learning tool?}

The second research question aims to examine how children use YTK for informal learning. Semistructured interviews (Table 4) were conducted with 10 of the respondents who have used YTK. The interview questions were formulated based on the themes in the questionnaire, such as media accessibility, app features, safety concerns, learning, and preferences. 
Table 4. Semi-Structured Interview Questions

\begin{tabular}{|c|c|c|}
\hline Themes & Questions & Responses \\
\hline \multirow{3}{*}{$\begin{array}{l}\text { Media } \\
\text { access }\end{array}$} & How do you access YTK App? & -I use my own phone. \\
\hline & Are you sharing with your parents or siblings? & Share with my mother. \\
\hline & Who set up YTK App account for you? & $\begin{array}{l}\text { Not sure. } \\
\text { I don't know. } \\
\text { My mother did it for me. }\end{array}$ \\
\hline \multirow[t]{2}{*}{ Preferences } & What do you like to watch on YTK App? & $\begin{array}{l}\text { Kpop songs } \\
\text { I watch McCreamy games show. } \\
\text { DIY show. } \\
\text { I watch educational shows like The Wiggle. } \\
\text { Movies like Harry Potter. } \\
\text { PUBG } \\
\text { Game Mobile Legends } \\
\text { Cooking shows } \\
\text { Learning English } \\
\text { Educational videos }\end{array}$ \\
\hline & What have you learn from the shows? & $\begin{array}{l}\text { New BTS songs (KPOP). } \\
\text { I learn how to play the game. } \\
\text { I made a pencil box after I watch DIY. } \\
\text { I learn new vocab and songs from The } \\
\text { Wiggle. } \\
\text { Learn their gaming skills. } \\
\text { I baked a chocolate cake during MCO. } \\
\text { I improve my English. } \\
\text { I use the square root formula. }\end{array}$ \\
\hline \multirow[t]{3}{*}{$\begin{array}{l}\text { Safety } \\
\text { Issues }\end{array}$} & $\begin{array}{l}\text { Did your mother or father ever worried about what } \\
\text { you watch on YTK? }\end{array}$ & $\begin{array}{l}\text { No. They didn't say anything. } \\
\text { No. } \\
\text { My mother ask me what I get from watching } \\
\text { Kpop? } \\
\text { They said watch more educational videos. }\end{array}$ \\
\hline & $\begin{array}{l}\text { Have you ever come across any unsuitable videos on } \\
\text { YTK? }\end{array}$ & $\begin{array}{l}\text {-No. but YouTube yes. } \\
\text { No. } \\
\text { Kissing videos } \\
\text { Lots of bad words } \\
\text { I see a video about how to kill other people. }\end{array}$ \\
\hline & What did you do after that? & $\begin{array}{l}\text { I click Block button. } \\
\text { Yes, and click not interested. }\end{array}$ \\
\hline Features & $\begin{array}{l}\text { What are the differences that you can see between } \\
\text { YTK and YouTube? }\end{array}$ & $\begin{array}{l}\text { YTK got colourful background, and } \\
\text { background music too. } \\
\text { YouTube don't have. } \\
\text { YouTube only has white background. } \\
\text { But the videos are limited. I can't find the } \\
\text { videos that I want. } \\
\text { I can use gaming tab. } \\
\text { YTK is safer. } \\
\text { I like the Explore tab. }\end{array}$ \\
\hline
\end{tabular}

Concerning media accessibility, most students use their own devices, except for a boy who shares a mobile phone with his parents. This finding shows that they can use their mobile phones regularly. In general, children who have their own mobile devices are more likely to have the chance to use YTK App. The 10 participants indicated that they have their own personal YTK account set up by their parents. Media accessibility plays an important role in this study as it helps to distinguish why most of the respondents were unfamiliar with YTK. 
Regarding app features, students were asked about the differences that they can see between YouTube and YTK. Student 4 stated, 'YTK has a colorful background with music. YouTube doesn't have'. The others agreed and indicated that YouTube only has a white background. Student 1 pointed out, 'YTK has limited videos. I can't find the video that I want'. This statement shows that YouTube has more videos to choose from. However, YTK App does limit its video choices as per the safety guidelines (YTK 2020). The limited selection of YTK can be changed if the users set up the appropriate age group in their profiles and if the intended videos do not violate any viewing protocol on YTK. Apart from that, The app offers a very kid-friendly feature - categorical tabs. The tabs are 'Recommended', 'Games', 'Shows', 'Music' and 'Explore'. These categorical tabs make it easier for children to browse for videos.

Topics on safety sparked an interesting revelation from the students. All of them agreed that they have seen foul words in YouTube's comment section. Another feature that makes YTK stand out is it does not have any comment sections like YouTube. The comment sections are not built-in as it usually portrayed inappropriate or negative comments which are not suitable for viewing. In fact, without the comments section, children can watch their videos without distractions. YTK does not have a comment section to eliminate purposely the need to comment on videos. The students also stated that they have seen inappropriate videos. Student 2 unintentionally saw 'kissing videos'. Student 9 saw 'how to kill people' under YouTube recommendations. They further clarified that they clicked on the 'Block' or 'Not Interested' buttons. These shocking examples confirm alarming safety concerns that are unmonitored on YouTube.

The discussion on the learning aspect shows the positive use of YTK to supplement in-class lessons. Students have used YTK to improve their vocabulary, speaking, and math skills. They mentioned shows such as 'The Wiggle Shows' and 'English Singsing' help them improve their English speaking skill. English is their second language and they are aware that they need to be exposed to the target language more. Hence, it is convenient for them to access educational videos with YTK.

Other valuable information from the interview was on students viewing preferences. Their preferences indicate how they use YTK as an informal learning tool. For example, Students 7 and 8 who like playing mobile games (e.g. Mobile Legends and PUBG) use the gaming tab on YTK to learn how to improve their gaming skills. They watch videos on gaming hacks and tips. Student 9 uses the explore tab to search for baking shows because he likes baking. The boy managed to bake a chocolate cake during the Movement Control Order. Student 3 said, 'I watch a DIY show on how to make a pencil box'. Student 10, who aspires to be a YouTuber, watches videos on how to speak confidently in front of the camera.

\section{Discussion}

\subsection{Safety concerns in YouTube lead children to use YTK App.}

The results of the study point towards several findings. Firstly, the respondents are not familiar with YTK yet they are aware of the safety concerns in using YouTube. The first finding is different from what is reported globally by Apptopia. The current application analytics report by Apptopia (an analytic company), supported by Braze (consumer engagement platform), showed that people were spending more of their time on YTK than any other online platform throughout the first three months of 2020 (Rasool, 2020). The data analyzed by the companies revealed that YTK was watched more than all other 34 services such as Netflix, Amazon's Prime Video, Hulu, Disney, and even YouTube (the main app) itself (See Figure 3). These emerging needs on the use of YTK App give a glimpse deduction in parents' intention to keep children entertained for hours while they stay home for the quarantine. 


\begin{tabular}{|c|c|c|c|c|c|c|}
\hline \multicolumn{7}{|c|}{ Top 10 Strosming Apps by Timo Spont in App in 2020* } \\
\hline & Olobal & & Europe & & us & \\
\hline 1 & K8? & YouTube Kids & KR? & YouTube Kids & K\$s & YouTube Kids \\
\hline 2 & NETrLIX & Netflib & NETFLIX & Netflib & NETFLIX & Netflix \\
\hline 3 & Doutibs & YouTube & Orutibs & YouTube & Onutibe & YouTube \\
\hline 4 & primenteo & Amazon Prime Video & srimenteo & Amazon Prime Video & Dfacept & Disneyt \\
\hline 5 & motster zet- & Hotstar & Guffeth & Twitoh & hulu & Hulu \\
\hline 6 & Besert & Disney+ & HBOGO & нво оО & mina viges & Amazon Prime Video \\
\hline 7 & tubi & Tubi & Dreept & Disney* & tubi & Tubi \\
\hline 8 & O new & Xigus Video & Omosu & BIGo LIVE & Roku & Roku \\
\hline 9 & hulu & Hulu & C & Crunchyroll & PLUTO & Pluto TV \\
\hline 10 & o mover & Tencent Video & anso & BBC iplayer & ocBs & CBS All Access \\
\hline
\end{tabular}

Figure 3. Top 1o Streaming Apps by Time Spent in 2020 (Apptopia)

However, the current study showcased a different perspective as the study was conducted in a rural town whereby most of the parents work in quarries and palm-oil plantations. The setting of the study thus affects children's perception of the use of YouTube and YTK. Respondents' inadequate digital exposure and awareness towards YTK also reflect their media accessibility. The questionnaire (Appendix 1) revealed that those who used YTK were most likely to have their own mobile devices compared to those who were not. Therefore, this indicated that possessing a mobile device is a luxury in the context of the study.

Secondly, the questionnaire reported higher safety concerns towards YouTube compared to YTK. The children despite being not familiar with YTK largely agreed that the original YouTube is more likely to be worrisome. YTK was launched in 2015 as a special video sharing platform dedicated to children. It only contains appropriate content (i.e. shows, songs, and educational videos) for children under a certain age group. The notion behind the app is to make navigating through the app safer and easier such that children can view suitable videos related to topics that they want to explore. In 2018, YouTube developers designed new filters to allow for more parental control (Izci et al. 2019). Parents can create individual profiles for each child under one account. They can also select the videos they want their children to watch or block any videos that they find not suitable for their children. Parents can turn off the search feature for younger children or open it to safe algorithms. The safety features of the app also include a timer, which parents can use to set children's screen time. The app can alert the child when the session is over, making parents less worried about their digital consumption.

A study from Hattingh (2017) recommended YouTube as an informal learning platform for preteens (aged 11-13 years) under parental guidance. This finding seems to contribute to the functional use of YTK because it includes parental involvement or control over the app usage. Parents can customize appropriate learning shows or channels in YTK for their kids. However, parental involvement should be minimized for an older age group of children because they will have their preferences.

\subsection{YTK App's features encourage informal learning opportunities among the children.}

The main objective of this study is to seek how children use the app as an informal learning tool. The focus-group interviews conducted with 10 participants managed to extract possible ways on how children can use the app for informal learning purposes. The app emphasis on safety features such as parental control, timer, search filter while also highlight other visual-appealing features (categorical tabs, colorful background with music, age-appropriate videos suggestions). As indicated by other studies (Dewi \& Deliana, 2019; Holland, 2016; Neumann \& Herodotou, 2020)- positive engagement, attention, and preference to the app help children to utilize YTK for learning purposes. 


\subsubsection{Multimodality of YTK interface}

The app itself offers eye-catching interfaces that require children to decipher certain multimodal functions such as the category icons on top, decorative image background, and the recommended video thumbnails.

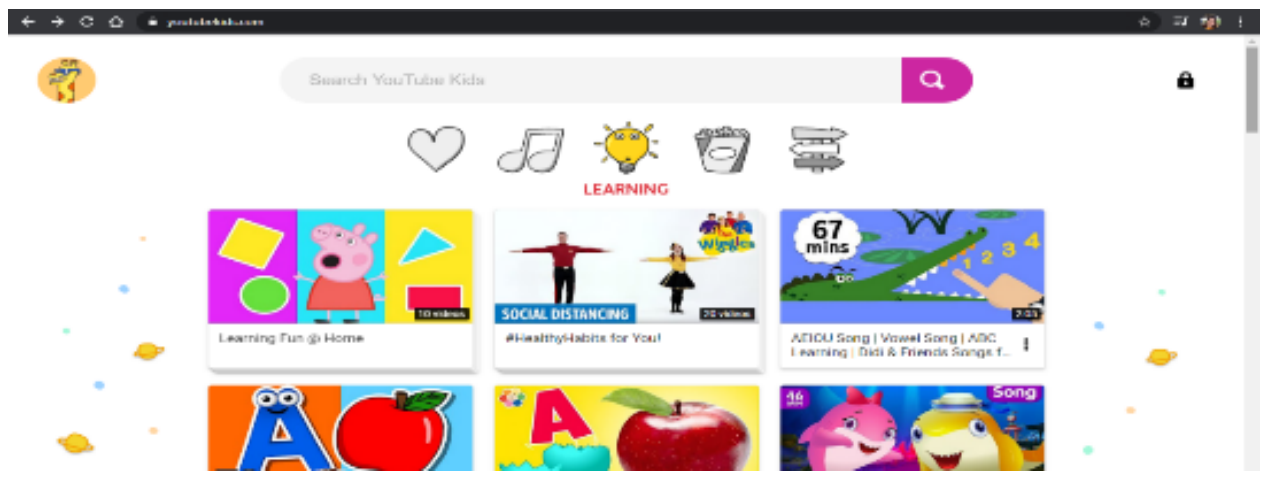

Figure 4. YTK interface

Once the child opens a video, he will gain access to more controls that overlay the video such as the back, pause, fast-forward, rewind, and next buttons.

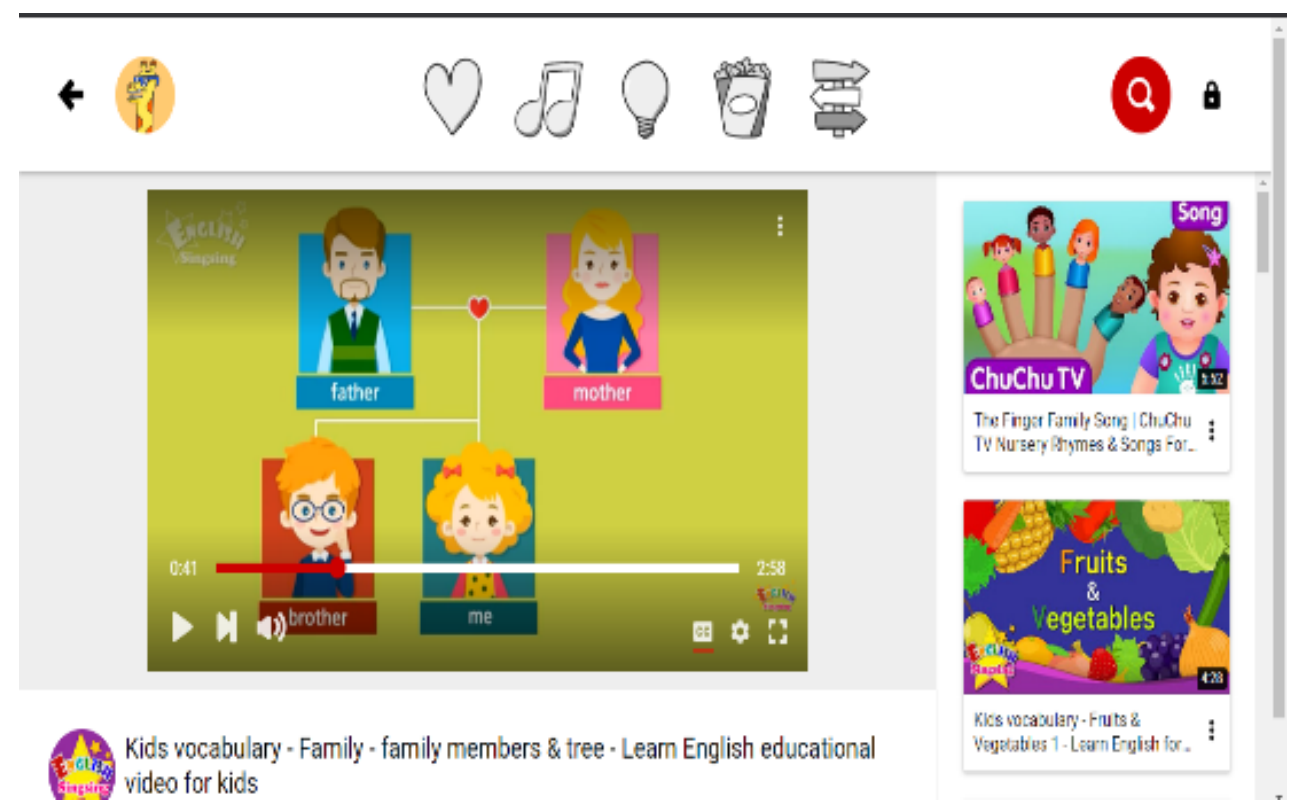

Figure 5. Sample video

Another multimodal feature of the app is the search function. The child can learn to search by using the microphone or search bar. Afterward, a selection of recommended videos will appear on the screen. 


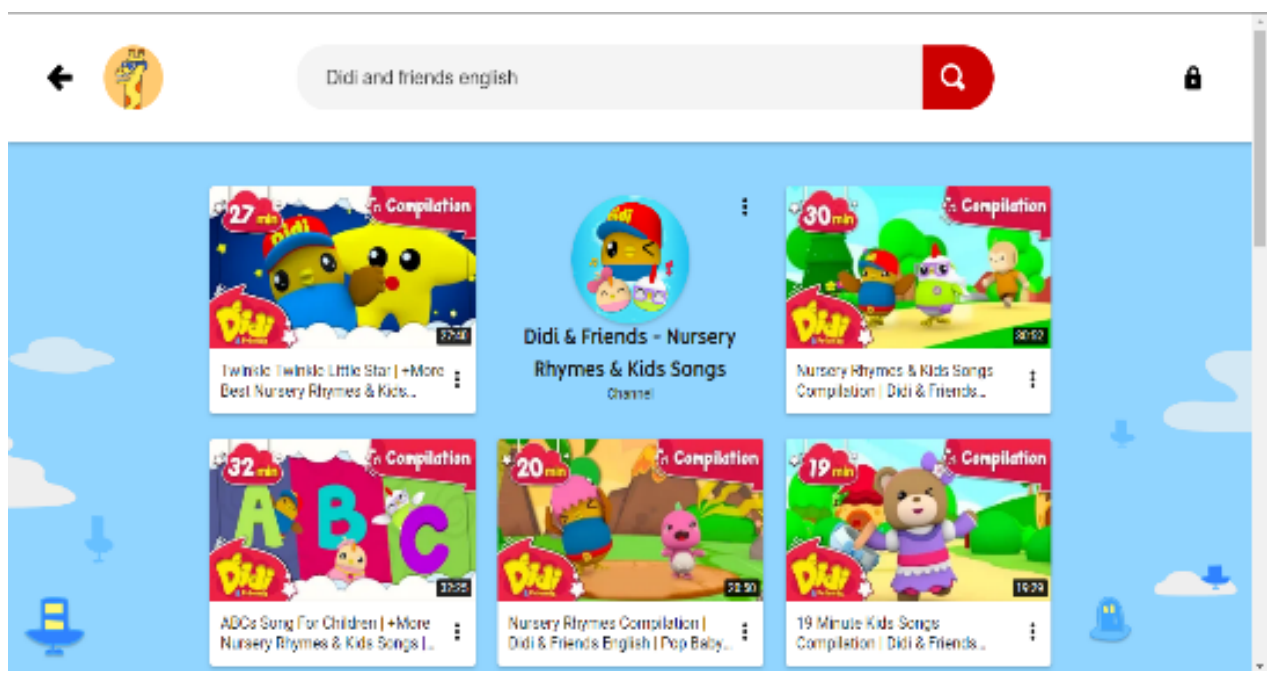

Figure 6. Search Bar

YTK offers easy access and helpful features to enhance informal learning experiences for children because they can browse for videos of their interest under the recommended tabs (categories) such as 'Shows', 'Gaming', 'Explore', and 'Music'. The afore-mentioned tabs play a vital role in dictating how children use them thus explaining the types of informal learning that present. Rogers (2014) outlined three forms of informal learning namely Self-directed learning, incidental learning, and unintentional learning. Self-directed learning occurs when the learner has the intention to learn and he is well aware that learning is taking place without being assisted by other people such as teachers, parents, or peers. For example, one of the interview participants managed to make a pencil box after she watched a DIY video. The second form of informal learning is Incidental learning whereby the learner has no intention to learn although the learner only notices it after completing the task successfully. Children who watched more informational videos found that they improve in certain skills over time. The third form of Informal learning is Unintentional learning where learners have neither the intention nor the awareness to learn. This form of informal learning is often not anticipated or acknowledge especially when children see it as leisure viewing.

In short, the categorical tabs of the app dictate how children use it as an informal learning tool. The app is nevertheless new yet it could be a suitable online platform for this critical time. Children are being confined at home and they are expected to be on their mobile phones all the time for online learning or other purposes. Presenting children with mobile phones has its challenges but it is inevitable now. Therefore, parents and teachers alike have to make a wiser decision on what platform to be used to keep them entertained as well as supplement their learning. Thus, a well-crafted platform like YTK could deliver more confidence in media usage as it offers safer and more informal learning opportunities where children can navigate on their own.

\section{Conclusion and Implication}

The research has answered the questions pertaining to why and how children use YTK App for informal learning. The ongoing pandemic has caused major uncertainties in many areas. Education is expected to be pursued in the comfort and safety of homes where children participated in online learning. This paper thus intent to present YTK as an entertaining yet safe mobile application to be used by children as an informal learning tool due to several reasons. Firstly, it gives parents the confidence in letting their 
children use the app as it covers promising safety features, unlike the original YouTube. Children can watch age-appropriate videos without having to worry about unsuitable or demeaning distractions. Parents would not have to worry about irrelevant interactions as the comments section is not available in YTK. Thus, YTK is much safer than YouTube. Secondly, the app is designed to meet children's preferences where they can maximize it for their entertainment and learning purposes. Video browsing is made easier with embedded categorical tabs in YTK. As children use the app, they eventually encounter three types of informal learning: self-directed learning, incidental learning, and unintentional learning. The three types of informal learning occur depending on children's viewing intentions and preferences.

Hence, this new app could be a perfect app for children, especially during this pandemic where many schools are still closed in most countries. YTK helps children be entertained while learning formally or informally. It can also serve as a resource for online learning. Allowing young children to be curious and make sense of their new-found information within a controlled environment is ideal as they are given the autonomy to direct their learning. Hence, children must be exposed to the fun yet effective tool while staying at home so that it helps to regulate their interest and motivation.

\section{Recommendations for Future Research}

Research on YTK is still underrepresented because the field is relatively new. This study centers on YTK as an informal learning tool amidst Covid-19. Researchers can further explore the function of the app in formal learning, blended learning, and others. Besides, future research could review parents' or teachers' roles in the use of YTK among different age groups of children.

\section{Acknowledgement of Funding}

The authors received support for the research and authorship of this article from the Ministry of Higher Education research grant FRGS/1/2018/SSo9/UKM/02/1 and for the processing fee from Universiti Kebangsaan Malaysia research grant GG-2019-011.

\section{References}

Abdulamir, A. S., \& Hafidh, R. R. (2020). The possible immunological pathways for the variable immunopathogenesis of COVID—19 infections among healthy adults, elderly and children. Electronic Journal of General Medicine, 17 (4), 1-4. https://doi.org/10.29333/ejgm/7850

Boileau, T. (2019). Informal Learning-Lifelong Learning in the 21st Century. Professional Practices, October, $173-208$. https://doi.org/10.4324/9781351289689-7

Brazendale, K., Beets, M. W., Weaver, R. G., Pate, R. R., Turner-McGrievy, G. M., Kaczynski, A. T., Chandler, J. L., Bohnert, A., \& von Hippel, P. T. (2017). Understanding differences between summer vs. school obesogenic behaviors of children: The structured days hypothesis. International Journal of Behavioral Nutrition and Physical Activity, 14(1), 1-14. https://doi.org/10.1186/s12966-017-0555-2

Brooks, S. K., Webster, R. K., Smith, L. E., Woodland, L., Wessely, S., Greenberg, N., \& Rubin, G. J. (2020). The psychological impact of quarantine and how to reduce it: rapid review of the evidence. The Lancet, 395(10227), 912-920. https://doi.org/10.1016/So140-6736(20)3046o-8

Burlington, C. (2016). How Does Digital Literacy Mediate Informal Learning on YouTube.

Buzzi, M. (2014). What Are Your Children Watching on YouTube? What Are Your Children Watching on YouTube? December 2011. https://doi.org/10.1007/978-3-642-34010-9

Dabbagh, N., \& Kitsantas, A. (2012). Internet and Higher Education Personal Learning Environments , social media , and self-regulated learning : A natural formula for connecting formal and informal learning. The Internet and Higher Education, 15(1), 3-8. https://doi.org/10.1016/j.iheduc.2011.06.002

Dewi, S. K., \& Deliana, S. M. (2019). Impact of YTK Impressions on Early Childhood Prosocial Behavior. 8(2), 315-322.

Dyosi, N. (2018). Using YouTube as an Informal Learning Tool for Children Neliswa Dyosi Master of Commerce ( Informatics ). June.

Eickhoff, C., \& de Vries, A. P. (2010). Identifying Suitable YouTube Videos for Children. Third Networked and Electronic Media Summit (NEM), 31(2), 1-6. 
Fleck, B. K. B., Beckman, L. M., Sterns, J. L., \& Hussey, H. D. (2014). YouTube in the Classroom : Helpful Tips and Student Perceptions. 14(3), 21-37.

Gill, P., Arlitt, M., Li, Z., \& Mahanti, A. (2007). YouTube traffic characterization: A view from the edge. Proceedings of the ACM SIGCOMM Internet Measurement Conference, IMC, 15-28. https://doi.org/10.1145/1298306.1298310

Hattingh, M. (2017). A Preliminary Investigation of the Appropriateness of YouTube as an Informal Learning Platform for Pre-teens BT - Advances in Web-Based Learning - ICWL 2017 (H. Xie, E. Popescu, G. Hancke, \& B. Fernández Manjón (eds.); pp. 101-110). Springer International Publishing.

Holland, M. (2016). How YouTube Developed into a Successful Platform for User-Generated Content. In Elon Journal of Undergraduate Research in Communications (Vol. 7, Issue 1). http://www.inquiriesjournal.com/a?id=1477

Izci, B., Jones, I., Özdemir, T. B., Alktebi, L., \& Bakir, E. (2019). YouTube \& Young Children: Research, Concerns and New Directions. Crianças, Famílias e Tecnologias. Que Desafios? Que Caminhos?, 81-92. https://repositorio.ipl.pt/bitstream/1040o.21/11658/1/Youtube $\% 26$ young childrene-book.pdf

Khairi-Fakhri, F. \& Nur-Ehsan, M. S. (2020). A Grammar-learning innovation for Malaysian Indigenous learners in an EFL context: The TurTense Mobile Game App. International Journal of Academic Research in Progressive Education and Development, 9(1), 220-235.

Lafrance, A. (2020). The Algorithm That Makes Preschoolers Obsessed With YouTube. https://www.theatlantic.com/technology/archive/2017/o7/what-youtube-reveals-about-the-toddler-mind/534765/

Lange, P. G. (2018). Informal Learning on YouTube. The International Encyclopedia of Media Literacy, 1-11. https://doi.org/10.1002/9781118978238.iemloogo

Latchem, C. (2014). Informal Learning and Non-Formal Education for Development Maximising Human Potential. 2.

Livingstone, D. W. (2006). Informal learning: Conceptual distinctions and preliminary findings. Counterpoints, 249 , $203-227$.

Marsh, J., Plowman, L., Yamada-Rice, D., Bishop, J.C., Lahmar, J., Scott, F., Davenport, A., Davis, S., French, K., Piras, M., Thornhill, S., Robinson, P. and Winter, P. (2015). (2015). Exploring Play and Creativity in Pre- - Schoolers' Use of Apps. www.techandplay.org.

Merriam, S. B., Caffarella, R. S., \& Baumgartner, L. M. (2007). Book reviews 269. 269-270.

Mohd-Iskandar, I., Nur-Ehsan, M. S. \& Tan, K. H. (2020). Game-Based Learning Platform and its Effects on Present Tense Mastery: Educational Research, 19(5), 13-26.

Muhammad-Asyraf, K. M. \& Nur-Ehsan, M. S. (2020). Watch'n Listen Ésfects of a Visual Approach on ESL Learner' Listening Comprehension in an ESL Context. International Journal of Innovative Science and Research Technology, 5(7), 216-220.

Myers, M. (2008). Qualitative Research in Business E Management.

Neumann, M. M., \& Herodotou, C. (2020). Evaluating YouTube videos for young children. Education and Information Technologies, 25(5), 4459-4475. https://doi.org/10.1007/s10639-020-10183-7

Nyumba, T. O., Wilson, K., Derrick, C. J., \& Mukherjee, N. (2018). The use of focus group discussion methodology: Insights from two decades of application in conservation. 2018(March 2017), 20-32. https://doi.org/10.1111/2041$210 X .12860$

Office of Communications. (2020). Children and Parents: Media Use and Attitudes. Ofcom, February 2020, http://stakeholders.ofcom.org.uk/binaries/research/media-literacy/october-2013/researcho7Oct2013.pdf

Pavitthra, A., Melor, M. Y. (2020). WhatSpeak: Audio-visual Digital Assessment in Enhancing Confident and Independent Speaking Skills. Universal Journal of Educational Research, 8(7), 2816-2824.

Rabiee, F. (2004). Focus-group interview and data analysis. Proceedings of the Nutrition Society, 63(4), 655-66o. https://doi.org/10.1079/PNS2004399

Rasool, A. (2020, April 5). Report: YTK is the Most Used Streaming App, Even more than YouTube. Digital Information World. https://www.digitalinformationworld.com/2020/o4/top-video-streaming-apps-by-time-spend-in2020-globally.html

Rogers, A. (2014). The Classroom and the Everyday: The Importance of Informal Learning for Formal Learning 1.

Saiful-Islam, A. S., Melor, M. Y., Denish, S., Rajeswari, C. K., Nabira, M., Jamaludin, B. (2020). Kahoot! Does Wonders: English Articles. International Journal of Academic Research in Progressive Education And Development, 9(1), 360-371.

Salmons, J. (2015). Cases in Online Interview Research. Cases in Online Interview Research. https://doi.org/10.4135/9781506335155

Schugurensky, D. (200o). The Forms of Informal Learning: Towards a Conceptualization of the Field. Wall Working Paper, 19(19), 33-36. https://doi.org/10.1016/j.radphyschem.2013.01.037

Scribner, S., \& Cole, M. (1973). Cognitive consequences of formal and informal education. Science, $182(4112), 553$. https://doi.org/10.1126/science.182.4112.553 
Sefton-green, J. (2020). Literature Review in Informal Learning with Technology Outside School A Report for NESTA Futurelab. January 2004.

Taber, K. S. (2018). The Use of Cronbach's Alpha When Developing and Reporting Research Instruments in Science Education. Research in Science Education, 48(6), 1273-1296. https://doi.org/10.1007/s11165-016-9602-2

Tan, E. (2013). Informal learning on YouTube: exploring digital literacy in independent online learning. Learning, Media and Technology, 38(4), 463-477. https://doi.org/10.1080/17439884.2013.783594

Tan, K. H., Woods, P., Azman, H., Abdullah, I. H., Hashim, R. S., Rahim, H. A., Idrus, M. M., Said, N. E. M., Lew, R., \& Kosem, I. (2020). COVID-19 insights and linguistic methods. 3L: Language, Linguistics, Literature, 26(2), 123. https://doi.org/10.17576/3L-2020-2602-01

Viberg, O., Andersson, A., \& Wiklund, M. (2018). Designing for sustainable mobile learning-re-evaluating the concepts "formal" and "informal." Interactive Learning Environments, o(o), 1-12. https://doi.org/10.1080/10494820.2018.1548488

Yew, K. K. W., \& Tan, K. H. (2020). Esl teachers' intention in adopting online educational technologies during covid19 pandemic. Journal of Education and E-Learning Research, 7(4), 387-394. https://doi.org/10.20448/journal.509.2020.74.387.394

Yoo, S. J., \& Kim, S. (2013). How and why college students use Web 2 . o applications : The role of social media in formal and informal learning How and why college students use Web 2. o applications: The role of social media in formal and informal learning. January 2019. https://doi.org/10.1504/IJWBC.2013.053242

YouTubeKids. (2020). A world of learning and fun, made just for kids. Retrieved from https://www.youtube.com/yt/kids/

\section{Appendix 1}

\section{Questionnaire - Exploring Informal Learning Opportunities via YouTube Kids among Children During} COVID-19

\section{Section A}

Tick (/ ) on the correct answer.

1. Gender

$\square$ Male

$\square$ Female

2. Age

a11 years old

$\square 12$ years old

3. Do You have your own smartphone?

$\square$ Yes

$\square$ No

4. Are you sharing the smartphone with your parents or siblings?

$\square$ Yes

$\square$ No

5. Tick (/) on the app that you have used before.

$\square$ YouTube

口YouTube Kids App

6. Tick (/) on videos that you like to watch on YouTube / YouTube Kids.

$\square$ Games

$\square$ DIY

$\square$ Hobbies

$\square$ Sports

$\square$ Educational

$\square$ Entertainment

Section B

Likert scale:

Strongly Disagree- 1

Disagree-2

Neutral-3

Agree-4

Strongly Agree -5 
1. Use of YouTube

\begin{tabular}{|l|l|l|l|l|l|}
\hline Items & $\mathbf{1}$ & $\mathbf{2}$ & $\mathbf{3}$ & $\mathbf{4}$ & $\mathbf{5}$ \\
\hline I use YouTube for entertainment. & & & & & \\
\hline I use YouTube for educational purposes. & & & & & \\
\hline My parents are not worried that I am using YouTube. & & & & & \\
\hline I have learned a lot of new things from YouTube. & & & & & \\
\hline
\end{tabular}

2. Use of YouTube Kids App

\begin{tabular}{|l|l|l|l|l|l|}
\hline Items & $\mathbf{1}$ & $\mathbf{2}$ & $\mathbf{3}$ & $\mathbf{4}$ & $\mathbf{5}$ \\
\hline I use YouTube Kids for entertainment. & & & & & \\
\hline I use YouTube Kids for educational purposes. & & & & & \\
\hline My parents are not worried that I am using YouTube Kids. & & & & & \\
\hline I have learned a lot of new things from YouTube Kids App. & & & & & \\
\hline
\end{tabular}

\section{Appendix 2}

Semi-Structured Interview Questions

\begin{tabular}{|c|c|c|}
\hline Themes & Questions & Responses \\
\hline \multirow[t]{3}{*}{ Media access } & How do you access YouTube Kids App? & \\
\hline & Are you sharing with your parents or siblings? & \\
\hline & Who set up YouTube Kids App account for you? & \\
\hline \multirow[t]{2}{*}{ Preferences } & What do you like to watch on YouTube Kids App? & \\
\hline & What have you learned from the shows? & \\
\hline \multirow[t]{3}{*}{ Safety Issues } & Did your mother or father ever worried about what you watch on YouTube Kids? & \\
\hline & Have you ever come across any unsuitable videos on YouTube Kids? & \\
\hline & What did you do after that? & \\
\hline Features & What are the differences that you can see between YouTube Kids and YouTube? & \\
\hline
\end{tabular}

